\title{
ドイツにおける保険会社ガバナンスに ついて
}

\section{柳 田 宗 彦}

\section{ロアブストラクト}

ドイツのガバナンス体制は，業務執行を行う取締役会を監視・監督する監 督役会が特徵となっている。この監督役会は, 一般的に半数は株主から選出 されるが, 残り半分は従業員から選出される。さらに, 監督役会が取締役会 のメンバーの選任および退任を決められるという強力な権限を持っている。 監督役会と取締役会という二層式となっており，この形式は EUの会社法に おいても選択できるガバナンス形態となっており, ドイッの保険会社として 選択している会社がある。さらに，相互会社の場合は，３分の 1 が従業員か ら選出だが，残り 3 分の 2 は契約者が選出することとなっており，契約者を 重視したガバナンスとして注目すべきものと考えられる。わが国の会社法に おいて従業員は債権者に過ぎないのに対して, 実態は従業員重視であり, ド イツのガバナンスはわが国のガバナンスにも参考となろう。

\section{ロキーワード}

ドイツ，ガバナンス，監督役会（監査役会）

\section{はじめに}

わが国の会社法においては株主が会社の所有者であり，株主のために経営 が行われることが前提となっている。また，従業員や契約者などのステーク

* 令和元年 6 月 14 日の日本保険学会関東部会報告による。

/ 令和元年 6 月 22 日原稿受領。 
ドイツに扔ける保険会社ガバナンスについて

ホルダーは会社においてはあくまでも債権者の位置づけでしかない。つまり， 従業員は，会社との間の労働契約に基ついて働き，その対価として顀金を受 け取る賃金債権を持っている者であり，契約者は，会社に対して対価として の保険料を支払い，会社に対してその商品やサービスの提供である給付を求 め，これを受け取る給付債権を持っている者でしかない。しかし，私は，保 険会社にとって，最も大事なステークホルダーは契約者であるべきだと考え ている。

保険会社のガバナンスを考える際に，自分自身がドイツ系の会社にいるこ ともあり，英米だけではなく，ドイツのガバナンスについても興味を持って いる。ドイツのガバナンスの特徴としては, 会社は株主だけでなくその他の ステークホルダーを含む全体のために運営されるべきであると考えられてお り，さらに，共同決定制度として従業員がガバナンス体制において重要な位 置づけを果たしていることが挙げられる。また，監督役会という取締役会に 対して強力な監視・監督を行う機関があることも特徴がある ${ }^{1)} 。$

まずは一般的な企業としてのガバナンスについて検討し，ヨーロッパの会 社としての SE におけるガバナンスについて検討した上で，わが国のガバナ ンスへの示唆を保険会社のガバナンスも含めて検討していくことする。

本稿においては，ドイツの保険会社ガバナンス，そしてその流れを受けた $\mathrm{EU}$ における会社法に基づく $\mathrm{SE}$ のガバナンス体制がどのようになっている かを検討し，わが国への示唆を得たいと考えている ${ }^{2)}$ 。

1）荒木尚志「コーポレート・ガバナンスと雇用・労働関係 $($ 上 $)$ 一比較労働法の 視点からみた日本型ステークホルダー・モデルの特徵と課題」商事法務1700号 18頁 (2004) は，コーポレート・ガバナンスには，株主価值を最大化することを 是とするシェアホルダー・モデルと, 株主以外の多様な利害関係者の利益をも 考慮した企業運営を是とするステークホルダー・モデルがあるとしており，日 本とドイツはステークホルダー・モデルだとしている。大杉謙一「コーポレー ト・ガバナンスの収斂と, その背景」法律時報84巻10号32頁 (2012) も同旨。

2）神田秀樹「企業法の将来一欧米のコーポレート・ガバナンスから何を学ぶ か」資本市場87号28頁(1992)は，日米でも盛んに紹介されたドイツの監査役会 を通じた共同決定制度は両国で受け入れられなかったが，その理由は全く異な 


\section{1. ドイツのガバナンス}

\section{（1） ドイツのガバナンスを取り巻く状況}

ドイツにおける企業形態 ${ }^{3)}$ は，組合（人的会社：Personengesellschaft） である，合名会社（Offene Handelsgesellschaft：OHG）および合資会 社（Kommanditgesellschaft：KG）ならびに法人（資本会社：Kapitalgesellschaft）である株式会社（Aktiengesellschaft：AG），株式合資会社 (Kommanditgesellschaft auf Aktien/KgaA), 有限会社 Gesellschaft mit beschränkter Haftung：GmbH）といった個々の事業の内容・規模に適した 会社形態が選択されている

合名会社は，2 人以上の無限責任を有する社員（出資者：Gesellschafter） から成る一元的組織の会社で, 社員は会社債権者に対し無限の直接責任を負 う組合である（ドイツ商法105条以下）。また，法人も社員になることができ る。有限会社 $(\mathrm{GmbH})$ が社員となっている合名会社を有限合名会社 （GmbH \& Co.OHG）と呼んでいる。合資会社は, 無限責任社員（persönlich haftender Gesellschafter）と有限責任社員（Kommanditist）から成る二 元的組織の会社であり，法人格を有さず，英米法の limited partnership に相 当する。なお，有限会社が無限責任社員になっている合資会社を有限合資会

っており，「アメリカでは理念的に，会社は株主のものであるべきだ，よって 従業員の経営参加には賛成できない, という理由であったと思います。日本で 受け入れられなかった理由は，私の推測によると，もうすでに会社は従業員の ものになっていたという認識からでしょう。」と指摘する。また，江頭憲治郎 「コーポレート・ガバナンスを論ずる意義」商事法務1364号 3 頁(1994) も「会 社法のタテマエはともかく, 実態論としては, 大会社はブルー・カラー, ホワ イト・カラー双方を含む『従業員』の利益を優先に運営されているという認識 において，ほとんどの商法学者の見解は一致してきたと思われる。」としてい る。

3）ドイツにおける企業形態については, デュッセルドルフ日本商工会議所「ド イツにおける現地法人設立の手引き（2016年更新）」，高橋英治『ドイツ会社法 概説』（有斐閣，2012）4～8 頁などを参照。 
ドイッにおける保険会社ガバナンスについて

社（GmbH \& Co. KG）と呼び，実務上広く利用されている。

株式会社は，社員（すなわち株主：Aktionär）の地位が株式（Aktie）と 称する細分化された割合的単位の形をとり，その株主が，ただ会社に対し各 自の有する株式の引受価額を限度とする有限の出資義務を負うのみで, 会社 債権者に対しなんらの責めに任じない会社である（株式法 1 条以下）。株式 会社は法人格を有しており，株式会社は基本的には上場等による公開を 前提にしているということができる。株式合資会社は, 無限責任社員 （Komplementär）と株主とから成る二元的組織の会社で, 株式会社の中の 一つの特殊形態の会社とされている（株式法278条以下）。無限責任社員につ いては合資会社に関する規定が準用され，したがって無限責任社員が代表権 及び業務執行権を有する。その他の事項については原則として株式会社に関 する規定が準用されるが，取締役会はなく，一定規模を超えない場合は監督 役会（Aufsichtsrat，監査役会と訳されることが多いが，本稿では監督役会 と訳す ${ }^{4)}$ 。また，監査役ではなく監督役として訳す。英語では Supervisory Board とされる。）の設置も不要とされている。有限会社は, 出資の金額を 限度とする有限の間接責任を負う社員（Gesellschafter）のみから成る会社 で，株主の有限責任の特色を保たせながら，汎用性や柔軟性を持った会社形 態である（有限会社法 1 条以下)。

形態別構成の特徵としては, 有限責任会社が529,970社と多く, 株式会社 が7,862社と少ない。ただし，1社あたりの売上高を見ると，欧州株式会社 および株式会社の売上高は高く，これらに大企業が含まれていることが分か る。

4）新山雄三「二つの監查役会（Aufsichtstrat）像一ドイツ監査役会史に打ける 理念型 (監査機関) と現実型(監督機関) 一」小室直人ほか編『企業と法 $($ 下 $)$-西 原寛一先生追悼論文集』219～240頁（1995，有斐閣）は，ドイツの監督役会は 理念的には監查機関としながら, 現実的には監督機関として機能している, と している。 
表 1 : 企業の形態別構成

\begin{tabular}{|c|c|c|c|c|c|}
\hline & 1990年 & 2008年 & 2016年 & $\begin{array}{c}\text { 売上高 } \\
\text { (千ユーロ) }\end{array}$ & $\begin{array}{l}1 \text { 社平均 } \\
\text { (ユーロ) }\end{array}$ \\
\hline 個人企業 & $1,545,264$ & $2,233,767$ & $2,176,944$ & 585,956 & 269 \\
\hline 組合 & & & & & \\
\hline 合名会社 & 173,294 & 265,868 & 14,847 & $43,972,610$ & $2,961,717$ \\
\hline $\begin{array}{l}\text { 合資会社 } \\
\text { 法人 }\end{array}$ & 85,219 & 137,153 & 15,744 & $113,947,422$ & $7,237,514$ \\
\hline 株式会社 & 1,717 & 7,862 & 7,862 & $859,794,449$ & $109,360,780$ \\
\hline 有限会社 & 263,341 & 465,694 & 529,970 & $2,340,239,357$ & $4,415,796$ \\
\hline 欧州株式会社 & & & 180 & $129,407,893$ & $718,932,739$ \\
\hline その他 & 35,139 & 76,543 & 67,459 & $422,651,333$ & $6,265,068$ \\
\hline 合計 & $2,103,974$ & $3,186,878$ & $3,266,429$ & $6,088,287,141$ & $1,863,897$ \\
\hline
\end{tabular}

（出所）1990年は高橋俊夫編著『コーポレート・ガバナンスー日本とドイツの企業 システムー』18頁（中央経済社，1995），2008年は風間信隆「ドイツ企業 における監查役会と共同決定」商学論纂54巻 5 号237頁 (2013), 2016年は Statistisches Bundesamt, Statistisches Jahrbuch 参照。

また，100大企業の形態においては，欧州株式会社および株式会社が多い ものの，株式会社だけでなく，有限会社，合資会社，合名会社などが入って いることが他の国と比べての特徵と言えよう。

表 $2:$ 100大企業の形態

\begin{tabular}{|l|r|r|r|r|}
\hline & 1982年 & 1992年 & 2006年 & 2014年 \\
\hline 個人企業 & 0 & 0 & 0 & 0 \\
株式会社 & 66 & 69 & 75 & 59 \\
株式合資会社 & 3 & 3 & 2 & 2 \\
有限会社 & 19 & 15 & 5 & 8 \\
合名会社 & 1 & 2 & 1 & 8 \\
合資会社 & 7 & 4 & 5 & 6 \\
有限責任合資会社 & 0 & 3 & 3 & - \\
欧州株式会社 & 4 & & 2 & 7 \\
その他 & 100 & 100 & 100 & 10 \\
\hline & & 5 & 5 & 100 \\
\hline
\end{tabular}

（出所）1982年と1992年は高橋俊夫編著『コーポレート・ガバナンスー日本とドイ ツの企業システム一』19頁（中央経済社，1995），2006年は海道ノブチカ 「ドイツ型コーポレート・ガバナンスの基調」商学論究 60 巻 $1 \cdot 2$ 号 58 頁 (2012)，2014年は Monopolkommission, Wettbewerb 2016 


\section{図 1：100大企業での人的結合}

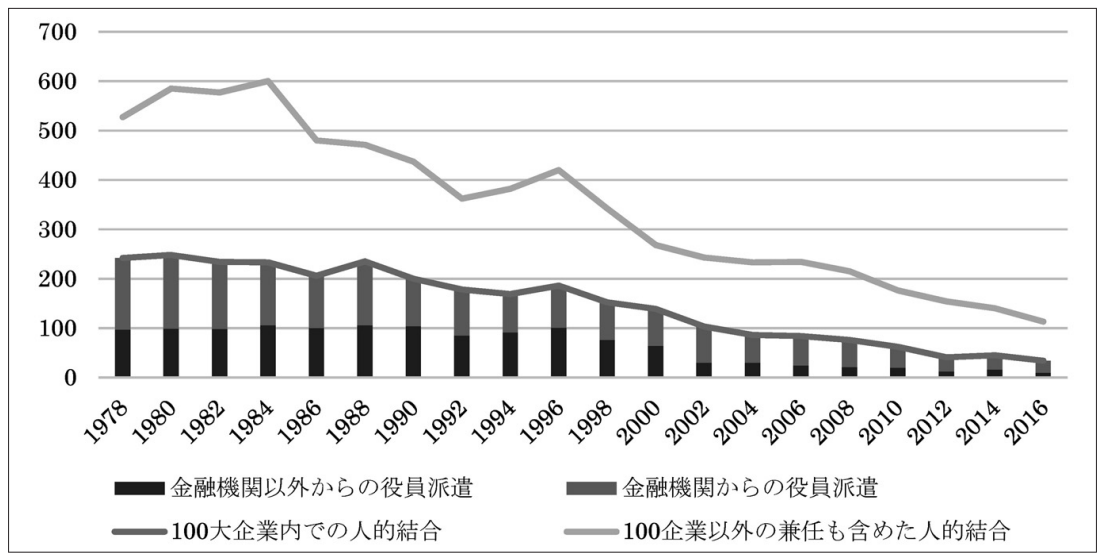

(出所) Monopolkommission, XXII. Hauptgutachten der Monopolkommission gemäß $\S 44$ Abs. 1 Satz 1 GWB, 2018

ドイツにおける企業における株式保有の特徴としては，銀行が企業との間 で緊密な関係を持っていることが挙げられる。そもそも上場株式会社が500 企業程度と少ないことに加え，ドイツの銀行はユニバーサルバンキングによ り，証券会社の機能も有している。株式の持ち合いが行われていたとともに， ドイツの銀行は寄託議決権（Depotstimmrecht）占を保有していることから, 株主から寄託を受けた株式による議決権により，株式会社に対して大株主と して議決権行使をすることを通じて，株主選出の監督役に就任することによ り企業支配が行われてきた ${ }^{6)}$ 。しかし，1990年代以降は銀行による保有が減

5）ドイツの銀行は商業銀行業務, 投資銀行業務, 証券ブローカー業務を営んで いる。銀行が証券業務を行っているため, 株主は株式の売買を銀行によって行 う。寄託議決権とは, 株式を購入した株主が株式を銀行に寄託し, さらにその 企業の株主総会の際に, その議決権の行使を書面によって銀行に委託する議決 権のことであるとされている（海道ノブチカ『ドイツの企業体制ードイツのコ ーポレート・ガバナンスー』112～113頁（森山書店，2005）。

6）陳浩「ドイツのコーポレート・ガバナンスの変容と監査役会改革の課題」立 命館国際研究 24 巻 2 号246頁 $(2011)$ 。 
少してくるとともに, 外国株主の保有が増加してきており, 英米的なガバナ ンスも求められるようになってきており，コーポレート・ガバナンス・コー ドに反映されているともされている。

\section{図 2 ：ドイツにおける上場企業株式保有構造推移}

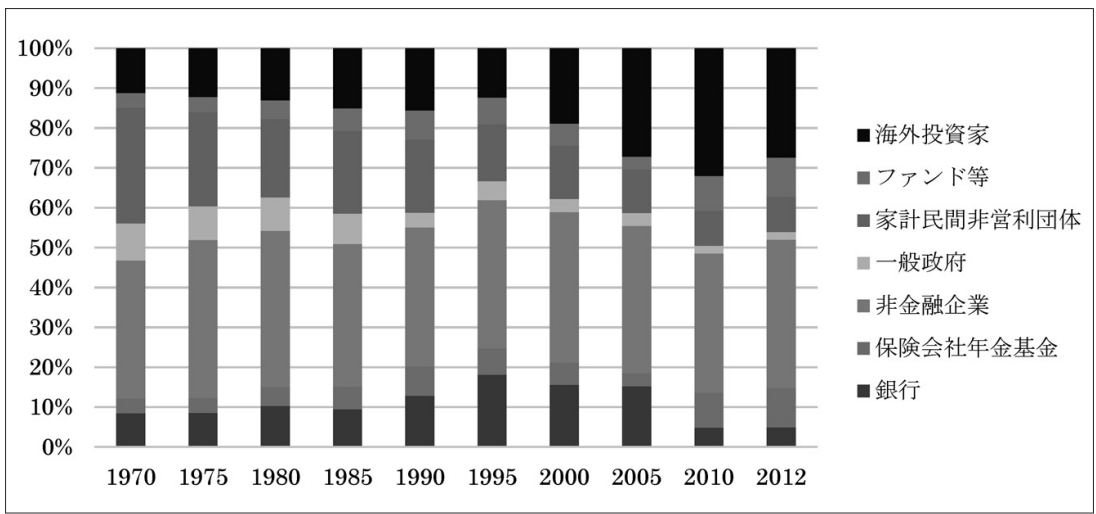

(出所) European Commission, WHO OWNS THE EUROPEAN ECONOMY? EVOLUTION OF THE OWNERSHIP OF EU-LISTED COMPANIES BETWEEN 1970 AND 2012, 2013

前述の株主としての監督役の選出は，銀行および保険会社による相互の監 督役の派遣につながっている。同時に銀行および保険会社などの取締役など が多数の会社の監督役を兼務することにつながっている7)。

企業以外の特徵としては, 労働組合が企業別ではなく, 産業別に構成され ていることがある。労使交渉は産業別組合による集中的な集団交渉と労働組 合とは分離された事業所委員会 ${ }^{8)}$ (Betriebsrat) による事業所レベルの従業

7）佐久間信夫『コーポレート・ガバナンスの国際比較』115頁（税務経理協会, 2007）によれば,「ドイツの大企業の役員のほとんどは・ドイツの銀行・保険 会社・製造業から派遣されている30人から40人の有カトップ・マネジメントた ちであった。とされている。

8）事業所委員会とは，法律（事業所組織法）に基づき，会社の本店，支店，工 場などの事業所ごとに設置される従業員の代表機関であり, その委員は当該事 
ドイッに扩ける保険会社ガバナンスについて

員代表の法的な制度が並立する二元的システムで行われている 合の組織化率はドイツにおいても低下しており，1960年が34.2\%だったのが， 2000年においては $21.6 \%$ となっている。

表 3 : ドイツの労働組合

\begin{tabular}{|c|c|c|}
\hline & 2017年 & 2004年 \\
\hline $\begin{array}{l}\text { 建設・農業・環境産業労働組合 } \\
\text { IG Bauen-Agrar-Umwelt }\end{array}$ & 254,525 & 424,808 \\
\hline $\begin{array}{l}\text { 鉱山・科学・エネルギー産業労働組合 } \\
\text { IG Bergbau, Chemie, Energie }\end{array}$ & 637,623 & 770,582 \\
\hline $\begin{array}{l}\text { 労働組合教員 } \\
\text { Gew. Erziehung und Wissenschaft }\end{array}$ & 278,243 & 254,673 \\
\hline $\begin{array}{l}\text { 金属産業労働組合 } \\
\text { IG Metall }\end{array}$ & $2,262,661$ & $2,425,005$ \\
\hline $\begin{array}{l}\text { 食品・嗜好品・飲食業労働組合 } \\
\text { Gew. Nahrung- Genuss- Gaststätten }\end{array}$ & 199,921 & 225,328 \\
\hline $\begin{array}{l}\text { 警察労働組合 } \\
\text { Gew. der Polizei }\end{array}$ & 185,153 & 177,910 \\
\hline $\mathrm{EVG}^{*}$ & 189,975 & 270,221 \\
\hline $\begin{array}{l}\text { 合同サービス産業労働組合 } \\
\text { ver.di }\end{array}$ & $1,987,336$ & $3,464,510$ \\
\hline 合計 & $5,995,437$ & $7,013,037$ \\
\hline
\end{tabular}

(出所) Deutsche Gewerkschaftsbund, Mitgliederzahlen ab 2010, 2018 (www.dgb. de/uber-uns/dgb-heute/mitgliederzahlen/2010，2019年 4 月 5 日最終閲覧） 組合名の日本語訳および2004年の数值は平澤克彦『企業共同決定制の成立 史』200頁（千倉書房，2006）参照。

\section{（2）ドイツにおける監督役会制度}

ドイツにおいて，二層式の経営組織が選択された場合，株主総会により選 任される監督役会（企業規模によっては, 半数又は 3 分の 1 を従業員代表と する，共同決定方式がとられる場合がある），監督役会から選任される取締

業所の従業員の中から選挙で選ばれる。従業員代表委員会または経営協議会と 訳されることもある。

9）山崎敏夫「ドイツの労資共同決定制度とその現実的機能」同志社商学 60 巻 $5 \cdot 6$ 号241 242頁 (2009)。 
役（Vorstand，株式法において取締役の規定はあるが，取締役会の規定は ない。経営執行を担うことから，執行役（会）とされることもある。本稿で は定訳の取締役会と訳す。英語では Management Board とされる。）が業務 執行を行うこととなっている。

図 3 : ドイツのガバナンス構造

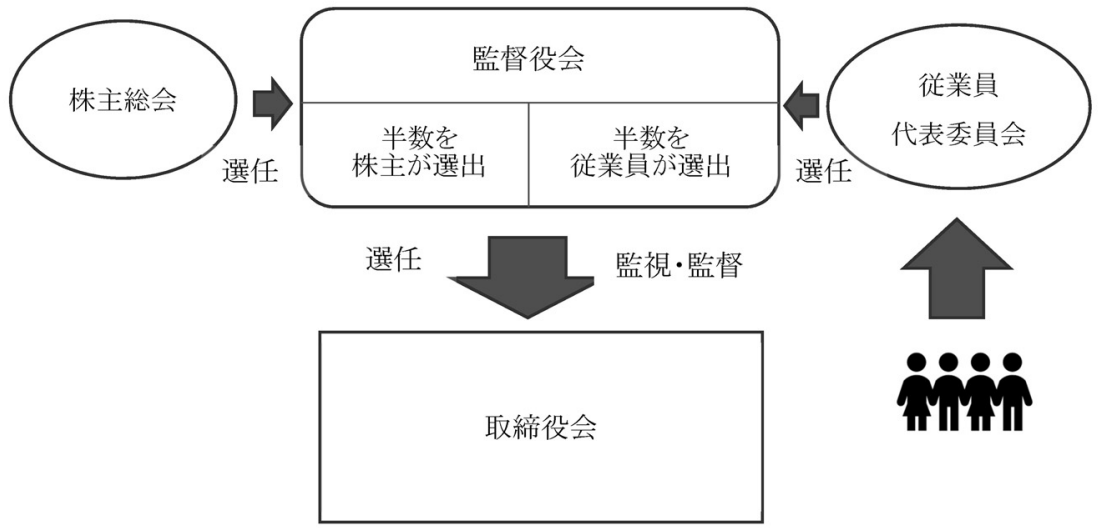

（出所）筆者作成

株主総会は，従業員代表を除く監督役の選任 ${ }^{10)}$ ，貸借対照表利益の処分， 取締役及び監督役会の構成員の責任解除，決算検査人の選任，定款の変更， 資本の調達及び資本減少の措置，設立又は業務執行の経過の検査のための検 査役の選任, 会社の解散を決定することができる。ただし, 取締役の選任は できない。

取締役会は，業務執行を行う機関であり，企業を代表し，経営業務を執行 している。

10）株主総会選任の監督役は，株主の 4 分の 3 により解任可能（株式法103条 1 項)。従業員選任の監督役は, 株主総会による解任はできない（株式条 4 項） が, 従業員の 4 分の 3 の同意により解任することが可能（共同決定法23条 1 項 1 文)。 
ドイッにおける保険会社ガバナンスについて

一方, 監督役会は, 取締役の選任（報酬も決定）, 取締役の解任（解任に は重大な事由が必要）をできるとされており, 監督役会は業務執行を行うこ とは原則としてできない（株式法111条 4 項 1 文）が, 法定決定可能事項と して取締役の業務規程の制定（株式法77条 2 項 1 文），授権資本の枠内での 新株発行の承認（株式法202条 3 項·204条 1 項), 企業買収, 公開買付けに 対する意見表明 (有価証券取得・買収法27条 1 項), 買収防衛策発動の承認 （有価証券取得・買収法33条 1 項）などを決定することができる。監督役会 は，業務執行を行う取締役に対する支配・管理的な機関として理解されてい る ${ }^{11)}$ 。なお，監督役は取締役と兼務できない。

人数は資本金により上限を法定（株式法95条）されており，下記の通りと なっている。

資本金150万ユーロまでは 9 名

資本金150万ユーロを超える場合は 15名

資本金1,000万ユーロを超える場合は21名

ドイツの監督役会の最も特徵とされるのが，共同決定方式 ${ }^{12)}$ である。 500 人超の従業員を雇用する資本会社（Kapitalgesellschaft：株式会社，有限会 社，協同組合など）には共同決定法が適用され，監督役会設立の義務が課せ られている。従業員代表の選出方法は, 従業員数が8,000名を超える場合に は間接投票, 8,000 名以下は直接投票（共同決定法 9 条 1 項 · 2 項）。従業員 代表は，管理的地位にない従業員が主ではあるが，管理的地位にある従業員

11）前田重行「ドイツ株式会社法に扔ける経営監督制度の改革」平出慶道ほか編 『現代企業法の理論一菅原菊志先生古稀記念論集』597頁（1998，信山社），菅 原菊志『取締役・監査役論〔商法研究 I 〕』35頁 (1992，大学図書)，新山・前 掲注4) 233 237頁参照。

12）須山光一「ドイツ企業共同決定制の過去・現在・未来」明星大学経済学研究 紀要46巻 1 ・ 2 号 3 頁 (2014) は, 「第二次大戦直後の西ドイッでは, 「ナチスに よる支配」という苦い歴史への反省から，企業の経済力を民主的に制御すべく， 企業の意思決定へ被用者を同権的に参加させる「高度な共同決定制度」がモン タン産業へ導入」したとしている。 
(leitender Angestellter) が含まれなければならないとされている。

従業員代表は，実務上は，事業所委員会の委員長である従業員が立候補し， 選任されるケースが多い ${ }^{13)}$ 。監督役会には従前取締役であった者が 2 名を超 えて入ってはならないとされており，原則として取締役であった時から 2 年 以内は監督役になることができないとされている（株式法100条 2 項 4 文）。 また，10社を超える会社での監督役を兼ねることはできないとされており (株式法100条 2 項 1 文), その計算の際に監督役会会長（議長と訳されるこ ともある。）の職にある場合はその会社数を 2 社としてカウントするとされ ている。なお，コーポレートガバナンスコード（5.3.2）では兼務数は 3 社 までとされている。

原則として，3 カ月に一回招集するものとされ，6 カ月に 1 回は，必ず招 集されねばならない $(110 \text { 条 } 3 \text { 項 })^{14)}$ とされている。

ドイツ株式法上の監督役会は1861年の普通ドイツ商法典（Allgemeine Deutsche Handelsgesetzbuch：ADHGB）において，任意機関としてではあ るが初めて採用され，その前身は当時の会社実務において採用されていた会 社のコントロール機関としての性格をもつ監督委員会（Verwaltungsrat） であった。監督委員会は大株主により構成され，出資者であるが，本業とし て業務執行を担当するのではなく，業務執行者を任命して，かれらを監督す る「大株主会」的な立場に立っていた。

1870年にドイツ普通商法監督役会制度が導入され，監督役会は相談役の継

13） 21 世紀政策研究所「会社法制のあり方に関する研究報告一ドイツに抒ける会 社法制の運用実態と比較して一」41頁 (2011)。吉村典久＝堀口朋亨「現代のド イツ企業に打ける共同決定の研究に向けて一準備的考察一」経済理論 372 号87 頁 (2013) にも同様の記述がある。

14）吉森賢「ドイツとフランスにおける二層型取締役会」横浜経営研究 21 巻 1 ・ 2 号59〜60頁 (2000)によると, 「ゲールムらの調査によれば, 281 社のうち年 4 回監査役会を開催する企業はわずか $13 \%$ あ゙り，大部分の $85 \%$ は法定最低回数 の年 2 回しか開催していない。」とある。なお， アリアンツ SE の2018年アニ ユアルレポートによると監督役会は年 6 回開催され，6の委員会を持っており， それぞれの委員会が開催されているとされている。 
ドイッにおける保険会社ガバナンスについて

承として義務づけられ，株主総会，取締役会とならんで株式会社の株主から 構成される第 3 の機関として制定された。監督役会には株式会社における業 務執行活動の全体を統制し, 会社の帳簿を閲覧し, 年次計算を監査し, 株主 総会に報告する権限があたえられ，取締役との兼任も認められていた ${ }^{15)}$ 。

1884年改正ドイツ普通商法において，(1)監督役の員数 3 名以上，(2)専門的 能力をもつ人材の登用を可能にするために監督役の適格要件から株主に限る という条件の撤廃，(3)監督役の業務を他人に委託することの禁止，(4)取締役 との兼任禁止，(5)取締役に対しいつでも業務執行に関する報告を徵求できる 権利を付与, (6)会社の利益のために必要と認めるときは株主総会を招集する 権利を付与, といった改定が行われたため,「大株主会」としての性格を喪 失し，監督機関として明確に位置付けられた

1897年ドイツ商法は，1884年改正法の規定をほぼそのまま承継し， (1)監督 役の報酬の規定の新設，(2)責任の規定の若干の変更，を行っている。

1937年旧株式法株式会社に関する規律は商法典から切り出され単行法化(1) 監督役会に対する業務執行権限の委託の禁止，(2)監督役会が必ず取締役を選 任しなければならないこととする，といった現行の監督役制度がほぼ完成し たと評価されている

監督役会における大事な役割として，監督役会会長がある。監督役会会長 は，監督役会の議長・招集権者であるとともに，可否同数の場合， 2 票目が 与えられることとなっている。取締役会との連絡空口であり, 株主総会から 選出された監督役から選任されることとなっている ${ }^{16)}$ 。監督役会会長の影響

15）前田・前掲注11) 596 598頁，高橋俊夫編著『コーポレート・ガバナンスー 日本とドイツの企業システムー』137頁（中央経済社，1995），神作裕之「ドイ ツに扮ける監査役制度の概要と展開」監査役協会有識者懇談会運営小委員会 1 ～ 2 頁 (2008) 参照。

16） 1976年共同決定法27条 2 項は, 監督役会会長は監督役会の 3 分の 2 の多数決 で選出されると定めている。一方，アリアンツ SEでは監督役会会長は取締役 でありCEO だった者が就任している。ただし，会長として選任されたのでは なく, アリアンツ SEの定款で監督役会の最高齢のものが会長に就くとされて 
力は強いとされており，例えば監督役選任のプロセスとして，監督役会会長 が取締役と相談して決めるのが大半である ${ }^{17)}$ ，とされている。また，取締役 は，監督役会に対する報告義務があり，さらに監督役会会長に対し，著しい 経営の障害, 重大な損失特定などの事項についての報告義務がある（株式法 90 条 1 項)。

\section{（3）共同決定方式}

ドイツに㧍ける従業員代表制度（従業員と労働組合の代表の双方が含まれ るが, 従業員と記載する。）の重要な特徵は，労働組合と事業所委員会とい う従業員の利益代表の二元性である ${ }^{18)}$ 。

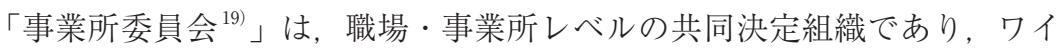
マール憲法のもとで制定された1920年事業所委員会法により始まっている。 その後ナチス政権下で廃止されたものの，戦後の1952年に再度制定され， 1972年の改正により現在の体系となっている。事業所委員会は労働者の労働 条件に関わるような社会的事項，募集，採用，配置転換，格付け，解雇，職 業訓練などの人事事項および事業上の経営問題に属する経済的事項に関与で

いる規定により就任している。

17）神作裕之「コーポレート・ガバナンス論と会社法」稲上毅 $=$ 連合総合生活開 発研究所編著『現代日本のコーポレート・ガバナンス』193頁（東洋経済新報 社, 2000 ), Johannes Semler, The Practice of the German Aufsichtsrat, Comparative Corporate Governance,269, (Klaus J. Hopt, Hideki Kanda, Mark J. Roe, Eddy Wymeersch and Stefan Prigge eds, 1998).

18）吉田修『ドイツ企業体制論』24頁（森山書店，1994）において，「企業レべ ルの共同決定が職場における直接的な共同決定に拠って立つべき強固な足とし て始めて実効力をもつように，職場レベルの共同決定もまた，上位の監査役会 における企業レベルの同権的な共同決定の制度を前提として，そして，相互に 補完的な関係をもつ重層的な構造を形成することによってこそその存在意味を もつことができるのである」とあるように，企業レベルと職場レベルの双方が 補完的に機能している, とされている。

19）事業所委員会に関する記述は, 早川勝「ドイツ事業所組織法(1)」同志社法 学52巻 4 号1474頁以下 (2000)に基づいて記載。 
ドイッにおける保険会社ガバナンスについて

きる一連の権利を有している。

事業所委員会は独立した法主体を構成し, 独立して従業員の利益を代表す る。事業場レベルでの従業員代表は, 組合員である必要はない ${ }^{20)}$ 。また，設 置が義務付けられてはいない任意の設定となっている。

事業所に雇用される従業員の人数に応じた最小限の事業所委員会委員数が 定められており，5２0人で 1 人から始まり，2,501〜3,000人で 21 人，以降， 従業員 3,000 人ごとに 2 人増えることとされている (事業所組織法 9 条)。ま た， 300 人以上から本務が免除される専従の職員を在籍に応じて置けること も定められている。複数の事業所委員会が存在する場合は, 中央事業所委員 会の設置が義務づけられ，コンツェルンレベルではコンツェルン事業所委員 会の設置ができるとされている。

2009年に行われた調査 ${ }^{21}$ によると，民間部門において，約45\%の従業員が 事業所委員会に代表されていた。一方, 約 $90 \%$ の（500人超の従業員を持つ） 大規模事業所においては，ほぼ事業所委員会が存在する ${ }^{22}$ ，とされている。

1980年代に入って, 1976年共同決定法適用企業数は増加し，1991年のドイ ツ再統一（Wiedervereingigung）後, 旧東ドイツ企業への導人によって共 同決定適用企業数は一貫して増加してきた。

20）ベルント・ヴァース（仲琦訳）「ドイツに打ける企業レベルの従業員代表制 度」日本労働研究雑誌630号14頁 (2013)。

21）連邦雇用庁に所属する研究機構の労働市場・職業研究所調査による。

22）ベルント・ヴァース（仲琦訳）前掲注20) 17，19２0頁。 
表 4 : 1976年拡大共同決定法適用企業数

\begin{tabular}{|c|c|c|c|c|c|}
\hline 暦 年 & 総 数 & 株式会社 & 欧州会社 & 有限会社 & その他 \\
\hline 1977 & 475 & 282 & - & 175 & 18 \\
\hline 1982 & 479 & 278 & - & 178 & 23 \\
\hline 1987 & 493 & 290 & - & 181 & 21 \\
\hline 1992 & 709 & 413 & - & 270 & 26 \\
\hline 1997 & 705 & 388 & - & 292 & 25 \\
\hline 2002 & 767 & 386 & - & 337 & 55 \\
\hline 2007 & 708 & 302 & 4 & 357 & 45 \\
\hline
\end{tabular}

（出所）風間信隆「ドイツ企業における監査役会と共同決定」商学論纂 54 巻 5 号 247頁 (2013)

一方，企業レベルでの共同決定方式の歴史を概観すると，「モンタン共同 決定法」(1951年)，「1952年経営組織法」「モンタン共同決定補足法」(1956 年),「1976年共同決定法」,「2004年三分の一参加法」と対象業種や従業員規 模に応じた法制定が行われてきた。

「モンタン共同決定法」(1951年)

- 石炭と鉄鋼産業における従業員数 1,000 人を超える株式会社，有限会社, 鉱山会杜に適用されるものであって，企業レベルでの共同決定を規制して いる。

- 監督役会は，原則的に株主代表 4 人，従業員代表 4 人，そして公的機関の 代表 3 人によって構成される。ただ企業資本金が1,000万と 2,500 万ユー ロになる場合，監督役は 15 人と 21 人である。

「1952年経営組織法」

芸術，マスコミ等の特定の業種（いわゆる傾向企業（Tendenzbetrieb）） の企業を除いた従業員500人を超える全ての株式会社（その他株式合資会 社，有限会社等も含まれる）に適用される。同法によれば，適用される株 式会社においては，監督役会構成員の 3 分の 1 は, 当該企業の事業に携わ る従業員によって選出されねばならないとされている。

「モンタン共同決定補足法」（1956年）

・モンタン共同決定法が適用される企業の親会社を対象としたものである。 
ドイツにおける保険会社ガバナンスについて

「1976年共同決定法」

・モンタン共同決定法が適用される企業を除き，2,000人を超える従業員を 雇用している資本会社に適用される。原則的には, モンタン共同決定法と 同様に，従業員の数に応じて監督役の数が決まり，監督役会における株主 代表と従業員代表は同数である。

$$
\begin{array}{ll}
2,001 \text { 人 } 10,000 \text { 人 } & 12 \text { 人 } \\
10,001 \text { 人 } 20,000 \text { 人 } & 16 \text { 人 } \\
20,000 \text { 人超 } & 20 \text { 人 }
\end{array}
$$

「2004年 3 分の 1 参加法」（3 分の 1 共同決定法とも訳されることがある。本 稿では 3 分の 1 参加法と訳す。Drittelbeteiligungsgesetz ; DrittelbG)

-「1952年経営組織法」から分離して制定された。500人〜 1,000 人の従業員 を雇用している「モンタン共同決定法」の対象企業を含む全企業，1,001 人から 2,000 人までの「モンタン共同決定法」の対象企業を除く全企業お よび 2,001 人以上の相互保険会社に適用される。この法律が適用される企 業の監督役会において, 従業員代表は 3 分の 1 の議席を占める。

\begin{tabular}{|c|c|c|c|c|c|}
\hline & \multirow{2}{*}{$\begin{array}{c}\text { 従業員代表 } \\
\text { の割合 }\end{array}$} & \multirow{2}{*}{$\begin{array}{l}\text { 監督役会 } \\
\text { の人数 }\end{array}$} & \multicolumn{3}{|c|}{ 従業員代表 } \\
\hline & & & 全 体 & 従業員代表 & 組合代表 \\
\hline \multicolumn{6}{|l|}{$\begin{array}{c}\text { 従業員規模 } \\
\text { 人以上 }\end{array}$} \\
\hline & 3 分の 1 & & & & \\
\hline \multirow[t]{2}{*}{2,001 人以上 } & 2 分の 1 & & & & \\
\hline & & 12人 & 6 人 & 4人 & 2 人 \\
\hline 10,001 人以上 & & 16人 & 8 人 & 6 人 & 2 人 \\
\hline 20,001 人以上 & & 20人 & 10人 & 7 人 & 3 人 \\
\hline
\end{tabular}

これらをまとめると，表 5 のようになる。

\section{表 5 : 監督役会の構成 (イメージ)}

（出所）佐村達生「ドイツの企業危機と共同決定性の課題」経営民主主義：新しい 参加時代のパイオニア誌22頁 $(2017)$ 
共同決定方式のメリットとしては，下記のようなものが挙げられている。

従業員の経営参加をとおして労資の協調的な基盤を強化することで安定的 な関係を築くとともに，外部の勢力からの圧力を回避しながら短期志向では ないかたちでの利益の確保や雇用の安定を重視した長期的な視点からの経営 の展開をはかるための重要な基盤をなしてきた。

業務執行機関と監督機関の制度的分離が行われているため, 監督機関が業 務執行機関からの独立性が強く，監督の責任についても明確化している ${ }^{23)}$ 。

監督役員が多様化し，広範囲な観点から経営の監督が行われるという点が 考えられる。すなわち, 監督役員に選任される人的範囲が既存の企業経営者 層とは大きく異なった層に拡大されることにより，監督役会構成員が多様な 層から構成され，経営者とは異なる従業員・労慟者が経営を監督する立場に 立ち, 広い観点から監督がなされるというメリットが存在しうると言われて いる。特に従業員，労働組合員といった既存経営者とは一定の距離を置いた 立場から監督がなされ，広い範囲の利益の考慮がなされうるのではないかと いう点である。また労働組合と経営者との先鋭な対立が避けられ，深刻なス トライキが減少していると言われている ${ }^{24)}$

またこれをメリットとするかは議論があるところであるが，株主により 取締役を送り込まれたとしても，半数を従業員代表が占めていることから， 株主総会選出の取締役全員を選出できるようにならないと過半数を株主が占 めることはできないという点がある。

共同決定方式のデメリットとしては，下記のようなものが挙げられている。 共同決定法の適用のある株式会社においては, 監督役会構成員の半数が従 業員代表から構成されることになるが，これらの従業員代表監督役員は必ず しも企業経営についての専門的知識や経験を有しているわけではないため, 監査能力としては不十分な状況にあり，監督役会全体としての経営監督機能

23）前田・前掲注11)611 612頁。

24）前田・前掲注11) $627 \sim 629$ 頁。 
ドイツに扔ける保険会社ガバナンスについて

の発揮に寄与していないという批判がなされている

\section{（4）保険会社のガバナンス体制}

ドイツにおける保険会社の会社形態は，株式会社または相互会社が主とな つており，1960年代から1990年代までは相互会社の数の方が株式会社の数を 上回っていたが，2000年以降は株式会社の方が多く存在している。

\section{表 6 ：ドイツにおける保険会社の形態}

\begin{tabular}{|l|r|r|r|r|r|r|r|}
\hline & 1960 & 1970 & 1980 & 1990 & 2000 & 2010 & 2016 \\
\hline 株式会社 & 125 & 140 & 196 & 281 & 317 & 301 & 272 \\
\hline 相互会社 & 646 & 527 & 406 & 352 & 287 & 267 & 247 \\
\hline 公法に基づく保険会社 & 16 & 16 & 12 & 47 & 25 & 17 & 18 \\
\hline その他 & 46 & 46 & 102 & 81 & 16 & 7 & 5 \\
\hline
\end{tabular}

(出所) Gesamtverband der Deutschen Versicherungswirtschaft, Statistical Yearbook of German Insurance 2018, 2018

保険会社のうちの株式会社については，1976年共同決定法により，監督役 会における株主代表と従業員代表は同数とされており，監督役会に株主代表 および従業員代表が半数ずつ入ることになることについては他の業界と同じ である。一方，相互会社については，「2004年 3 分の 1 参加法」の対象とさ れるため, 従業員は監督役会の 3 分の 1 を占めることとなり, 残りの 3 分の 2 は契約者からなる社員総会または社員総代会から選任された者が監督役と なる(保険法189条)。

\section{2. ヨーロッパ株式会社のガバナンス}

\section{(1) SE のガバナンス体制}

欧州会社法成立に30年を要したのは ${ }^{26)}$, 会社の運営機構に従業員を参加さ

25） 前田・前掲注11) $627 \sim 629$ 頁。

26） 2000 年 12 月 $7 \cdot 8$ 日のニースサミットにおける政治的合意（ニース合意）に 
せるべきか（機関参加）について，加盟国の利害対立が鮮明となり，閣僚理 事会で意見の一致が困難となったことにある。このため，1989年からは， SE 制度に関する規則案と SE における従業員参加に関する指令案に法案を 分割して，特定多数決による成立を図ろうとした。しかし，この手法におい ても解決の糸口を見出せないまま ${ }^{27)}$ ，ユーロ導入とニース条約交渉という局 面を迎えた2000年12月，加盟国首脳による政治的合意（「ニース合意」）がな され，ふたつの法案は一挙に成立に向かうことになった ${ }^{28)}$ 。

過去の議論は, 会社法の視点で,「会社の構造は二層制と一層制のどちら が会社の運営システムとして好ましいか」, あるいは従業員参加の視点で 「機関参加を行うには二層制が適当か，一層制が適当か」というものであっ た $^{29)}$ 。

欧州株式会社（Societas Europaea：SE）の経営構造は欧州株式会社法 (Council Regulation (EC) No. 2157/2001 of 8 October on the Statute for a European company (SE)の Title III (Structure of SE)）において定められて いる。

欧州株式会社の経営構造として，まず株主総会が必置の機関とされる。そ れ以外については，監督機関と管理機関を置く二層式システム（Two-tier system, Dualistisches System）と，監督と執行の機能を兼ね備えた経営機

より，同月15日，閣僚理事会の常駐代表委員会（Coreper）で規則案掞よび指 令案確定，20日には雇用・社会政策委員会で全会一致で合意している。2001年 9 月 4 日の欧州議会に抒いて, 規則案㧍よび指令案ともに承認。10月 8 日, 若 干の字句修正が加えられたものの, 欧州株式会社に関する両法案が原案どおり 閣僚理事会で成立した。

27）直前まで反対していたのはスペイン 1 か国。しかし最終的に, 従業員の経営 参加の参照条項（reference provisions）を国内法に受容する否かの選択の余地 を加盟国に残すことで15ケ国の合意が形成された。

28）上田廣美「ヨーロッパ会社法の成立と EUに扔ける従業員参加」日本 EU 学 会年報23号233頁 $(2003)$ 。

29）上田·前掲注28) 235頁。 
ドイッにおける保険会社ガバナンスについて

関のみを置く一層式システム（One-tier system, Monistisches System）の 二つのシステムから選択できる（欧州株式会社法38条) ${ }^{30)}$ 。

また，欧州株式会社は，従業員を経営に参加させなければならない。経営 参加には, 従業員側への情報提供および従業員側との協議を行う情報参加方 式と，監督機関への経営参加方式とがある。最低資本金は，12万ユーロ。共 同決定制を有しない国において，合併により欧州株式会社を設立する場合に は，共同決定制を導入する必要はない。他方，共同決定制を有する国におい て，合併により欧州株式会社を設立する場合には，共同決定制に関する従業 員の権利は保障されるといった特徵をもっている ${ }^{31}$ 。

2018年時点での欧州株式会社の数は3,000社である。そのうち, 最も多く 設立されているのがチェコ ${ }^{32}$ ，次いでドイツとなっている。経営構造は，二 層式が 8 割を占めているが, ドイツの SE では二層式が半分は超えている程 度となっている。

表 7 ：SE 形態をとっている企業の国別ガバナンス体制

\begin{tabular}{|l|c|c|c|}
\hline & 一層式 & 二層式 & 不 明 \\
\hline チェコ & 56 & 1998 & - \\
\hline ドイツ & 222 & 258 & 11 \\
\hline オーストリア & 12 & 6 & 1 \\
\hline 英国 & 37 & 1 & - \\
\hline
\end{tabular}

(出所) SE EUROPE, SE Companies, 2018

30） 21 世紀政策研究所・前掲注13) 26～27頁。

なお，共同決定について，「共同決定はもはや企業法ではなく労働法の問題 である」との発言もあり，EU 全体で機関参加の法制度化を検討するとした従 前の固執がみられなくなった。

31）平田光弘「欧州統合と欧州株式会社 $-\mathrm{EU}$ 企業の競争力強化に向けた基盤作 り」経営力創成研究 4 巻 1 号56頁 (2008)。

32）チェコにおいて SE 企業が多く設立されているのは, $\mathrm{EU} へ の$ 進出を目指す 第三国へ販売する目的で設立された無人企業が多いとされている。 
EU 各国における従業員の経営参加の程度とコーポレート・ガバナンスの 関連は，ドイツ，オランダ，チェコ，スロバキアにおいて経営参加が大きく 二層式経営体制の国もあれば，経営参加がなく一層式の構造の英国，ベルギ ーといったように，区々となっている33。

\section{(2) AG から SE への移行}

SE を選択することのメリットとデメリットは,メリットは(1)国境を越え た M\&A が容易になる，(2)監督役会の員数が縮減されたり，従業員選任監 督役の比率が縮小したりすることで，監督役会の運営が迅速かつ柔軟になる ことがあげられている。また，デメリットとしては，(1) SEへの移転には相 当の経済的コストを要する，(2)移転に向けた協議が難航する場合がある ${ }^{34)}$, とされている。

ドイツの上場企業で最初にこの欧州株式会社へと生まれ変わったのは，ド イツの保険会社である Allianz AG である。2006年 2 月の臨時株主総会でド イツの株式会社から欧州株式会社への変更が承認され，2006年10月13日に Allianz SE が新たに誕生した。欧州株式会社法では二層式と一層式のいずれ かを選ぶことができ, Allianz SE は，伝統的なドイッモデルを選択し，ドイ ツ型の共同決定を導入している。ただし，ドイツの株式法とは異なり欧州株 式会社の場合には定款において監督役会の規模を定めることができ，監督役 の数は株主総会において決定されることになる。ドイツの株式会社では監督 役会の規模は株式法で規定されており，従業員が 2 万人超の場合は 20 人であ り, 移行前のドイツ法人 Allianz AG ではその数は 20 人であった。しかし Allianz SE においては意思決定の効率を考慮して定款に 12 人に縮小して定め られた ${ }^{35)}$ 。

33）本田良巳「ヨーロッパの企業(1)」大阪経大論集65巻 2 号 242 頁 $(2014)$ 。

34） 21世紀政策研究所・前掲注13) 43 頁。

35） BASF が SE に移行する際も監督役会の人数を 20 人から 12 人に削減している。 
ドイツに扔ける保険会社ガバナンスについて

表 8 ：ドイツ株式会社と欧州株式会社の監督役会の比較

\begin{tabular}{|c|c|c|c|c|c|}
\hline & \multicolumn{2}{|c|}{ 2006アリアンツ AG } & & \multicolumn{2}{|c|}{ 2007アリアンツ SE } \\
\hline 株主選出 & 11名 & $\begin{array}{l}2 \text { 名元取締役 } \\
2 \text { 名大学教授 } \\
7 \text { 名他社経営者 }\end{array}$ & 5 名退任 & 6 名 & $\begin{array}{l}1 \text { 名元取締役 } \\
5 \text { 名他社経営者 }\end{array}$ \\
\hline 従業員選出 & 9 名 & $\begin{array}{l}8 \text { 名従業員 } \\
1 \text { 名労働組合 }\end{array}$ & $\begin{array}{l}7 \text { 名退任 } \\
4 \text { 名選任 }\end{array}$ & 6 名 & $\begin{array}{l}4 \text { 名従業員 } \\
\text { jち } 1 \text { 名 UK } \\
2 \text { 名労働組合 } \\
\text { うち } 1 \text { 名フランス }\end{array}$ \\
\hline & & 20名 & & & 12名 \\
\hline
\end{tabular}

(出所) 筆者作成

Allianz SE においては労資同数の共同決定が採用されているので監督役会 メンバーの内，資本側代表は 6 名，労働側代表も 6 名と定款に規定されてい る。Allianz SE は, ドイツの株式会社ではないので, ドイッの共同決定法は 適用されず，経営者側と従業員の代表組織である特別交渉機関との間で経営 参加の方式について交渉がおこなわれ，また監督役会の運営方法も，主にそ れぞれの会社で独自に決定されている。Allianz SEでは監督役副会長は 2 名 で，1名は資本側であり，この資本側副会長は，会長が欠席の場合には第 2 票目を行使することができる。もう1名は労働側であり，この副会長には第 2 票目を行使する権限はない。労働側代表監督役の選出に関しては, 今まで の共同決定法の場合のように数力月もかけて費用のかかる選挙をおこなう必 要はなく，コンツェルン事業所委員会で決定されることになっている ${ }^{36)}$ 。ま た，ドイツの AGでは，監督役員をドイツ以外から選任できなかったが， $\mathrm{EU}$ 域内からも選任できるようになっており，英国とフランスから 1 名ずつ 選任されている。

陳・前揭注6)252頁。

36）海道ノブチカ「ドイツ型コーポレート・ガバナンスの基調」商学論究60巻 $1 \cdot 2$ 号62 63頁 $(2012)$ 。 
表 9 ：ドイツ株式会社と欧州株式会社の監督役会の比較

\begin{tabular}{|c|c|c|}
\hline & ドイツーAG & $\mathrm{EU}-\mathrm{SE}$ \\
\hline 監督役会の規模 & 法定 & 定款で定める \\
\hline 従業員代表の選任 & 選挙(費用と期間がかかる) & 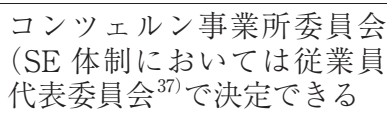 \\
\hline 従業員代表の割合 & $\begin{array}{l}\text { 法定(従業員数に応じて } 1: 1 \\
\text { または } 2: 1 \text { ) }\end{array}$ & 定款で定める \\
\hline 従業員代表の国籍 & ドイッ国民 & EU 域内の国民 \\
\hline
\end{tabular}

(出所) 筆者作成

\section{3. 日本におけるコーポレート・ガバナンス}

\section{（1） 日本におけるコーポレート・ガバナンスの課題}

日本の企業におけるコーポレート・ガバナンスの特徵は, 「日本的経営モ デルの特徵として挙げられる要素を簡単に整理すると, 第一に, 終身雇用と 年功賃金制に代表される企業内部組織，第二に，企業内部から昇進した経営 者と銀行を中心にした企業統治のしくみ（企業の効率的運営を担保する監視 と規律付けのしくみ)，第三に，企業グループや系列といった企業間の長期 的な取引関係の構築といった 3 つ要素を挙げることができる。」と年りされ ている。このうちのコーポレート・ガバナンスにあたるが,「第二の企業統 治については, 多くの文献が, 日本の場合, 企業の主たるステークホルダー (利害関係者) は従業員である考えられていると指摘している年)。このため,

37） EU の労働者関与指令に基づいて設置されている従業員代表委員会。労使協 議会と訳されることもある。国によって従業員代表委員会の内容や決定権限は 異なり，ドイッ，オーストリアなどは従業員のみで構成されているのに対して， フランス，スペインなどは使用者側も参加することとなっている。

38）平成18年度年次経済財政報告（経済財政政策担当大臣報告）一成長条件が復 元し，新たな成長を目指す日本経済一(内閣府，2010）（http://www5.cao.go. $\mathrm{jp} / \mathrm{j}-\mathrm{j} / \mathrm{wp} / \mathrm{wp}-\mathrm{je} 06 / 06-00202 . \mathrm{html}, 2019$ 年 4 月 5 日最終閲覧）。

39）伊丹敬之『日本型コーポレートガバナンスー従業員主権企業の論理と改革』 53頁以下（日本経済新聞社，2000）では，日本企業にみられる従業員主権の企 業の在り方を，米国的な「資本」主義との対比で「人本」主義という言葉で表 
ドイツに扔ける保険会社ガバナンスについて

日本の企業では取締役が内部出身者によって占められ，社外の取締役の割合 が低いという慣行がみられる。日本では株式持合いの慣行もあり,メインバ ンクが主たる債権者であると同時に，株主でもあるという関係がみられたた め, メインバンクも一定の監視機能を果たしてきたと考えられている。内部 者から構成される取締役会と, その結果として発生する経営執行と監督の未 分離は，従業員には利益を生むが株主には利益を生まない投資プロジェクト を選択するという可能性を伴っているが，債務による圧力，あるいはメイン バンクの存在が，こうしたモラル・ハザードを抑制してきたとも考えられて いる。としている。

つまり，日本の会社法が想定しているのは「会社は株主のもの」であるが， 実態としてのコーポレート・ガバナンスは「株主と経営者の関係」を主とす る構成と異なっており，従業員が主たるステークホルダーであり，従業員の 自律性を重視する会社システムが成立している，とされてきた。ただし，

1991年に米国，英国，ドイツ，日本の経営者に対して行われたアンケー ト ${ }^{40)}$ によると、「会社は誰のために存在するのか」という問いに対して, 米 国，英国の経営者はほほ４分の 3 が「株主のため」と答えているのに対して， ドイツ，日本の大多数の経営者は「すべての利害関係者のため」と答えてい る。また, 不況下で雇用の削減か配当の削減かの選択を迫られたとき,「配 当と雇用どちらを優先するか」の問いに対して，米国，英国の大多数の経営 者は「配当優先」とし，日本は $100 \%$ が「雇用優先」，ドイツは過半数が「雇 用優先」であったとされている。

また，このアンケートの回答が実際の数值として2008年のリーマンショッ ク後の米国，英国，ドイツ，日本の単位費用（総労働費用を生産量で割った ものであり，労働分配率と近似している）を比較したところ，アンケート通 りの反応が行われ，日本やドイツでは単位費用を上げて雇用を守ろうとして

現している。

40）吉森賢「日本型会社統治制度への展望一日米欧比較による視点」組織科学27

巻 2 号24頁以下 $(1993)$ 。 
保険学雑誌 第 646 号

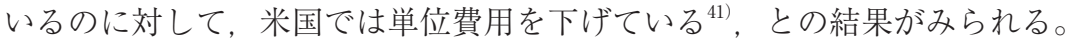

ただし，アンケートが行われた当時から30年近く経過しており，わが国に おいてもガバナンスへの取組が行われていることから，ガバナンスも変化し てきている,こともあろう。

\section{（2） わが国の保険会社のコーポレート・ガバナンスへの示唆}

保険会社に特有な会社形態である相互会社は，株主のいない会社であり， 契約者が最高決議機関である社員総代会の構成員という建付けを取ってる。 また，株式会社であっても，株主である親会社が変わることもあり，会社に とって長い関係を有しているのは，従業員と契約者であり，株主は変わるも のであり安定していないと考えている。それため, シェアホルダー・モデル よりもステークホルダー・モデルのほうが生命保険会社にはふさわしいと考 えている。そのような観点からは，ドイツの従業員の経営参加制度はわが国 の今後のコーポレート・ガバナンスへの示唆となりうるではないかと考えて いる。特に, ドイツの相互会社において監督役会の 3 分の 2 を契約者が選任 し, 残りの 3 分の 1 を従業員代表が選任されるようにできているのは契約者 の経営への関与としてはとても大きいといえよう。

生命保険会社41社のガバナンス体制について見たところ，監査役会等設置 会社が多い。また，アニュアルレポートを見る限りにおいて，公共的な位置 づけにある大会社であるにもかかわらず，社外取締役がいない会社も見受け られる。ただし，定款において譲渡制限がかけられた非公開会社であれば, 社外取締役を設置することは求められていないことから，これらの会社には 設置義務はない ${ }^{42)}$ 。しかしながら，社外取締役は，会社から独立した客観的

41）岩井克人『経済学の宇宙』309～310頁（日本経済新聞出版社，2015）。なお， 英国はアンケートに反して単位費用を上げており，これは英国が金融立国であ るからではないか, としている。

42） 2019年時点で検討されている会社法改正においても, 非公開会社には社外取 締役の設置が求められていない。 
ドイツにおける保険会社ガバナンスについて

な立場からコーポレートガバナンス・内部統制の監督を期待されているもの であり ${ }^{43)}$, 設置義務はなくとも，ガバナンスの向上の観点からは取り入れる ことが望ましいであろう。

ドイツの監督役会に近いガバナンス体制は，日本においては，取締役会が 執行役会のメンバーを選任できる指名委員会等設置会社が最も近いといえよ う。ただし，取締役が執行役を兼任できることや選任方法も異なり，同じで はない。指名委員会等設置会社は，ガバナンス強化の観点から導入されたも のの，社長の権力の源泉でもあった個別の報酬決定権と取締役候補を指名す る権限が委員会に移行することもあり移行が少なかったともされている ${ }^{44}$ 。 しかし，生命保険会社においては，41社中 6 社が指名委員会等設置会社を採 用しており，上場会社全体よりは高い割合を示しており，ガバナンスへの取 り組みが行われているといえよう。

なお，支店をその他に分類しているのは，保険業法において設置が求めら れているのは日本における代表者のみであり, 取締役, 取締役会, 監査役な どの機関の設置が求められていないため, 任意の会議体が設置されているの みであり, ガバナンスとしては弱くなる懸念がある。

43）経済同友会「2017年度経営改革委員会提言社外取締役の機能強化「3つの心 構え・5つの行動」一実効性の高いコーポレートガバナンスの実現を目指し てー」3 頁の「社外取締役が果たすべき役割として期待されるもの」において 8 割を超える最も高い割合の回答が寄せられている。

44）浜辺陽一郎「監查等委員会設置会社の導入によるガバナンス改革の行方」青 山法務研究論集第 9 号17頁 (2014)。 


\section{表10：日本の生命保険会社41社のガバナンス体制}

\begin{tabular}{|c|c|c|c|c|c|}
\hline & $\begin{array}{l}\text { 監查役等 } \\
\text { 設置会社 }\end{array}$ & $\begin{array}{c}\text { 監查等委員会 } \\
\text { 設置会社 }\end{array}$ & $\begin{array}{c}\text { 指名委員会等 } \\
\text { 設置会社 }\end{array}$ & その他 & 合 計 \\
\hline 相 互 & 3 & & 2 & & 5 \\
\hline 株 式 & 6 & & 1 & & 7 \\
\hline 子会社 & 15 & & & & 15 \\
\hline 外 資 & 9 & 1 & 3 & & 13 \\
\hline 支 店 & & & & 1 & 1 \\
\hline 合 計 & 33 & 1 & 6 & 1 & 41 \\
\hline
\end{tabular}

※原則として，2018年に発行されたアニュアルレポートにおける記載に基づいている。

※上場または日本の保険会社グループ以外の子会社の場合は「株式」「「外資」は外国保険 会社の子会社，「子会社」は日本の保険会社または保険会社グループの子会社であるこ とを示している。プルデンシャルグループは日本の保険会社の子会社ではないため, 「外資」としている。

\section{表11：日本の上場会社のガバナンス体制}

\begin{tabular}{|c|c|c|c|r|}
\hline & 監査役等設置会社 & 監查等委員会設置会社 & 指名委員会等設置会社 & 合 計 \\
\hline 第一部 & 1,546 & 537 & 57 & 2,140 \\
\hline 第二部 & 335 & 153 & 3 & 491 \\
\hline マザーズ & 214 & 66 & 5 & 285 \\
\hline JASDAQ & 532 & 934 & 69 & 3,630 \\
\hline 合 計 & 2,627 & 178 & 4 & ( \\
\hline
\end{tabular}

（出所）日本取引所グループのコーポレート・ガバナンス情報サービスにより作成 https://www2.tse.or.jp/tseHpFront/CGK010010Action.do?Show = Show （最終確認日2019年 6 月 2 日）

\section{4. 今後への課題と方向性}

ドイツにおける株式会社の観点から，欧州株式会社での二層式経営構造の 導入と，実際のドイツの株式会社から欧州株式会社への移行を見てきた。ド イツの共同決定方式は純粋なガバナンス構造としての観点から取り入れられ ているのではなく，従業員の事業所ごとの経営参加の全社レベルへの展開と して行われてきたことがうかがえた。

ドイツのガバナンス構造は, 米国のガバナンスと並んで, 比較検討対象と なる構造であるが, その生成からなぜこのような形態をとっているのか, そ 
ドイッに抢ける保険会社ガバナンスについて

れを支える事業所単位での活動と関連付けながら検討していくことが必要で あると考えている。

ドイツの共同決定方式に関しては，労働法からのアプローチとしては経営 への労働者の参加として捉えているのに対して, 会社法からのアプローチと してはガバナンスに労働者がかかわってくるととらえているように見える。

ドイツにおける従業員参加の経営方式は, 事業所レベルと経営レベルの双 方で行われることにより機能しており, 労働組合による権限の獲得の成果で あるといえよう。ドイツにおいて従業員参加に関しては，EUにおける会社 法制定の際にも従業員参加を提唱していたことから見られるように，従業員 参加は当たり前であるととらえられている。確かに, 法律で決められている ために人数が硬直的であるとか, 人数が多すぎる, 従業員代表を選ぶ選挙に 時間と費用がかかりすぎると，従業員代表が経営の知識がないといった課題 の指摘 ${ }^{45)}$ はあるものの，その中で経営を行うことにより，失業率を低く抑え， $\mathrm{EU}$ の中でも成功した国となっていることからも従業員参加をなくすことは 考えていないようである。

ドイツにおけるコーポレート・ガバナンス・コードは, 英米的なコーポレ ート・ガバナンスの導入に基づくものと考えられるが，その序文にはドイツ の監督役会についての記載があえてなされており，「監督役会の構成員は， 株主総会において株主によって選出される。ドイツでは, 従業員も監督役会 に参画し，500名を超える従業員を有する企業及び2,000名を超える従業員を 有する企業では, 監督役会のそれぞれ 3 分の 1,2 分の 1 が従業員の代表者 により構成される。2,000名を超える従業員を有する企業では，監督役会議 長が事実上，株主を代表し，議案の賛否が同数の場合には，決定投票権を有

45） EUの会社である SE に移行したドイツの会社は, 監督役会の人数の削減や 選出方法の簡便化といったことにより, 欠点とされている点を緩和して従業員 参加制度を継続している。例えば, アリアンツやBASF などの SE は, EU 会 社法で定款で定めることが認められたことから, 定款において監督役会の人員 数を 20 名から 12 名に削減し, 従業員代表を 6 名とするとともに, 選挙ではなく コンチェルン事業所協議会との協議により決定するといった対応を取っている。 
する。従業員代表及び株主により選出された株主代表は，企業の利益を最大 にする責務を平等に負う。 ${ }^{46)} 」 と$ 自国の制度について説明することにより， 理解を求めようとしている。

ただし，わが国にドイツの従業員参加の制度を取り入れることができるか と問われると，そもそも，わが国においてはまだ多くの経営者が当該企業の 従業員であった場合が多いとされており, そのような経営者は従業員代表と しての位置づけでもあるとも考えられ，従業員の雇用や給与を守る傾向があ り ${ }^{47)}$, さらに, ドイッと組合の位置づけも異なることから, 従業員代表の選 出方法も検討が必要となる。

今後, 検討すべき課題としては, ステークホルダーの中でも顧客をどのよ うに捉えていくべきかであると考えている。業種によって顧客とのつながり 方は異なるものの，保険業のように長期に顧客との関係が続く場合に，交代 がある株主や経営者よりも顧客との関係が長い場合や, ターンオーバーの激 しい会社であれば従業員よりも長い場合だってあり得る。そのような場合に， 株主のための会社であり，株主の意見を最優先とすることが望ましいとは限 らないと考えている。ただ，外部取締役が顧客代表となりうるかについては， 疑問であり，どのようにすべきかの回答は私自身としても出ておらず，今後 さらに検討を進めていくこととしたい。

（筆者はアリアンツ生命保険株式会社勤務）

46）翻訳は金融庁の「コーポレートガバナンス・コードの策定に関する有識者会 議（第 1 回）」において使用されたドイツ・コーポレートガバナンス・コード （仮訳）の翻訳に本稿における訳語との統一を図って使用している。(https:// www.fsa.go.jp/singi/corporategovernance/siryou/20140807/08.pdf, 2019年 4 月 5 日最終閲覧)。

47）経済社会総合研究所「日本企業の雇用調節手段とコーポレート・ガバナンス ステークホルダーモデルによる検証」ESRI Discussion Paper Series No. 136, 14 頁 (2005)によると, 日本の上場企業において, 外部出身取締役の比率が高いほ ど, 一時休業の拡大, 早期退職の優遇, 希望退職者の募集を行う傾向にあるこ とが示されている。 